\title{
- THE ACQUISITION OF ENGLISH INTONATION BY JAPANESE ELEMENTARY LEARNERS: EFFECTS OF A PHONOLOGICAL CONSTRAINT
}

\author{
ISAO UEDA ${ }^{1}$ \\ Osaka University, \\ Japan
}

U radu se ispituje intonacija u engleskom jeziku kod izvornih govornika japanskog koji su na početnom nivou. U istraživanju je učestvovalo petoro ispitanika, a korišćene su rečenice iz Wells (2006). Prikazane su i upoređene intonacione konture kod ispitanika i kod izvornih govornika engleskog. Autor smatra da se tri komponente akcenta - visina, jačina i dužina - odvojeno usvajaju, i da se kod japanskih učenika najpre i najlakše usvaja razlika u visini tona. Takođe je primećeno da za razliku od učenika početnog nivoa napredniji učenici prevazilaze tzv. efekat OCP (Obligatory Contour Principle), fonološku zapreku koja se tiče postojanja dva susedna sloga sa istim tonom.

Ključne reči: intonacija u engleskom, usvajanje, fonologija L2, strani akcenat, zapreke u razvoju.

\section{INTRODUCTION}

As the status of English as a world language has become unquestionable, its acquisition as a second language has called our attention. In Japan, English is the second language, which most people are required to study at least for three years at junior high school. Most people continue on to study it at senior high school for another three years, with many of them further studying it at universities or colleges. However, English and Japanese are different in a considerable number of aspects, which is a target of research interest in applied linguistics. The acquisition of English phonology has also been investigated and discussed by an enormous number of researchers. Obviously, the difference in sound structure between the two languages results in "Japanese accent," quite noticeable in the learner's interlanguage. There are numerous publications from

1 Kontakt podaci (Email): uedais@lang.osaka-u.ac.jp 
highly theoretical journal articles for professionals to down-to-earth how-to books for laymen, which either aim to explain the mechanism for acquisition, or emphasize overcoming the accent found in practical language use.

However, the treatment of the Japanese accent is rather limited. First, in most of the publications, the focus is placed on the problems with the acquisition of English segments rather than that of prosody. Usually, English segments are listed one by onewith detailed descriptions of their articulatory characteristics. They are often followed by notes of how Japanese learners fail to produce those segments, which do not exist in the Japanese phonetic inventory, or which are more or less pronounced in a different way in English. For example, Takebayashi, et al. (2013) have an introductory textbook on English phonetics that deals with English segments in 93 of 150 pages; the chapters on prosody are only 40 pages. The most comprehensive upper-level introduction for advanced students, Takebayashi and Saito (2008), devotes almost half of the volume to a detailed description of the segments. However, chapters on prosody are about one-third the volume. In a recent how-to book on pronunciation by Kamiyama (2008), whole pages are devoted to segmental training. Thus, segmental acquisition seems to be treated more seriously than prosodic acquisition.

Second, let us overview how prosody is handled and "taught" in textbooks. Most of them describe the prototypical Japanese-accented prosody of Japanese learners. However, we find unbalanced descriptions here. In most literature, focused points are quite limited, which are listed in the following.

(1) Points emphasized in literature

1. Japanese learners stick to the CV syllable structure of Japanese, having a vowel added after each consonant.

2. English is a stress-timed language, while Japanese is mora-timed.

3. The mora-timing is transferred into the learner's interlanguage, where each syllable is produced with equal length of time. This spoils the isochrony of English, having stressed syllables appear at regular intervals.

4. The accent systems of Japanese and English are different, the former being pitch accent, but the latter stress accent. This difference causes the Japanese learner to embody the accent mostly by pitch. Put in a word, the pitch accent system is transferred.

5. The lexical pitch accent may obscure the phrasal and sentential prosody.

These points in focus rather clearly exhibit that the general concerns in prosodic acquisition are: (1) the difference in syllable structure, (2) the timing difference, and (3) the distinct accent systems; with relevant problems caused by (1), (2) and (3). Thus, other aspects of prosodic acquisition are scantily presented, and, some of them are completely neglected. A further problem for these descriptions is that only typical examples of Japanese-accented English are provided, which do not come from case studies actually conducted. The examples are those that the authors of the literature think to be prototypical. This tendency reveals itself clearer as the prosodic units become higher. Thus, the acquisition of intonation is the part that is most perfunctorily treated in many textbooks. However, the crucial problem is the lack of case studies on how 
English intonation is acquired step by step, which should shed light on the mechanism of the acquisition of higher prosodic units.

Given the situation stated above, this study aims to inquire into the acquisition of English intonation by Japanese learners. In fact, the acquisition of intonation has already been discussed in some previous studies including Saito (2006), Saito and Ueda (2007), Ueda and Saito (2010 and 2012). Although these studies do investigate into the acquisition of intonation based on results of case studies, they only examine advanced learners and problems therein. The present study attempts to "fill the gap" and investigate how the intonation system of elementary learners develop until they reach the stage of advanced learners reported in the previous researches. After bridging the gap, I present a basic model for the process of acquisition of intonation. By so doing, it is hoped that any individual process can be explained by referring to the model, whether it is consistent with, or deviated from the idealized process of acquisition.

\section{ACQUISITION OF INTONATION BY ADVANCED LEARNERS}

Let us start by making a survey of the facts discussed in the previous studies mentioned above. It is pointed out in Saito and Ueda (2007) and Ueda and Saito $(2010,2012)$ that advanced learners have acquired most of the basic patterns of English intonation, for example, tone patterns like falling, rising, etc. and tonality, namely dividing prosodic units into proper pieces. However, they do have a problem with tonicity and show a tendency to put the nucleus on wrong lexical items. What is interesting here is that they always misplace the nucleus on lexical items of particular syntactic categories. These are Interrogatives, attributive adjectives, negative particles and some personal pronouns. Some examples from Ueda and Saito (2010) are shown below, with accented words in capital letters.

(2) Syntactic categories bearing mis-accentuation

1. WHAT class are you attending this afternoon? (Interrogative)

2. I found his essay in the OLD book. (Attributive Adjective)

3. John HASN'T finished the work. (Negative Particle)

4. YOU should do the washing. (Personal Pronoun)

It is easy to understand that this misplacement may be a source of misinterpretation by listeners. Consider the example 4 . If this utterance is addressed to the listener in an out-of-the-blue context, the prominence on YOU allows a contrastive interpretation and the listener may interpret this as "You, not anyone else, should do the washing." Ueda and Saito (2010) go on to argue about some possible reasons for the errors. Although they reserve any decisive conclusion, they suggest that this may be caused by a sort of transfer from Japanese that is governed by the syntactic structure. More specifically, the syntactic unit embedded most deeply in the sentence is produced with maximal stress (Cinque 1993). However, no matter what the reason may be, it is evident that this type of errors emerges from phonology-syntax interface. This should be interpreted as a constraint governing phonology-syntax interface. Put in a different way, because 
intonation falls under the domain of phonology, it is a problem of how syntax should be compromised in the phonological system.

What is also intriguing is that this kind of errors is found among the subjects (all English major university students) who are supposed to have topmost proficiency in English in Japan. In the follow-up study, Ueda and Saito (2012) report that some of these subjects, after studying English intensively for one year, acquired the proper tonicity with or without instructions on nucleus placement rules of English, while others did not. This means that advanced learners have to overcome this type of constraint to obtain native-like proficiency in English intonation.

\section{THE FIRST STAGE OF ACQUISITION}

We discussed in the previous section that advanced learners have a problem with phonology-syntax interface. Then, how do elementary learners start acquiring intonation from the very beginning to the advanced stage? As has already been mentioned, there have been no case studies which captures the process of acquisition in a longitudinal fashion. In her very comprehensive researches on Japanese-accented English, Sugito does report some acoustic characteristics of eight Japanese subjects (Sugito 1996, 2012), but she does not mention the proficiency level of them explicitly, nor does she pursue the process of their development.

Given the lack of empirical data, let us look for how the beginning stage of acquisition is described in literature. First, Shimizu (1995) emphasizes the importance of the role of intonation and points out that in Japanese-accented English, the pitch range tends to be short, which prohibits enough ups and downs of pitch movement. Sugimoto (2003) exemplifies and compares acoustic properties of English and claims that Japanese is monotonous in terms of pitch movement, stress alternation and segmental length, compared with English. Considering these characteristics and other prosodic properties shown in (1), let us consider the starting point for the elementary learners with a flat, monotonous utterance and without notable pitch movement, stress alternation, or length difference, as illustrated in (3).

(3) This is a pen.

English speakers' version is shown in (4) for comparison.

(4) This is a pen. 
Needless to say, the prosodic illustration in (3) is abstracted and idealized to show the Japanese-accented prosody. In reality, every learner, even if he/she is elementary, modulates the production, so that in the utterance the pitch goes up and down slightly, and syllables may have a more or less distinction in loudness and length.

To see how the system develops from this first stage, I asked five first-year university students to participate in an experiment. They are majoring in technology and though they have studied English at high school, their English is judged to have an extreme Japanese accent by native teachers of English. First let us observe some examples with falling intonation. Henceforth, the native prosodic pattern is written below for comparison. Most of the target sentences are taken from Wells (2006).

(5) You mustn't \worry. (Subject B)

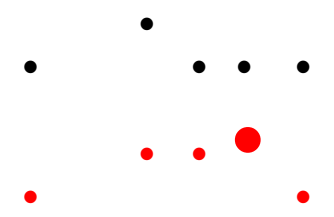

This example indicates that each syllable is produced with the same length and stress. On the other hand, the pitch goes up at "must," then goes down, and keeps flat thereafter. The next example also shows the rise of the pitch on one syllable.

(6) It was remarkably $\backslash$ good. (Subject E)

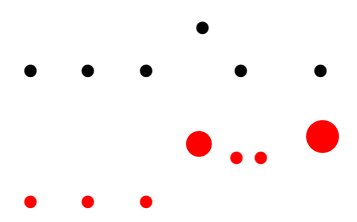

In the target, the pitch rises on the onset syllable "-mark-" and keeps the high position before the nucleus "good." On the contrary, Subject E's pitch stays low in the first syllables. After it rises on "-mark-", it falls down to the bottom and keeps the position to the end. Let us see one further example.

(7) We're planning to fly to Italy. (Subject A)

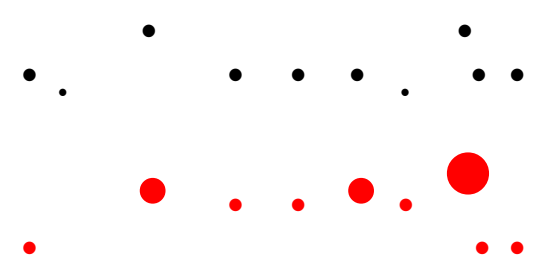


While the target pitch pattern exhibits a rise at the onset "plan-" and keeps the high pitch to the nucleus "I", Subject A raises the pitch on "plan-." The pitch immediately falls low until the second rise on "I", and again the pitch falls right after "I". The three examples suggest that there are rises in the contour of the subjects, but after each rise the pitch falls down immediately.

Next, let us go over some more examples, this time with rising intonation.

(8) You want to talk to/who? (Subject C)

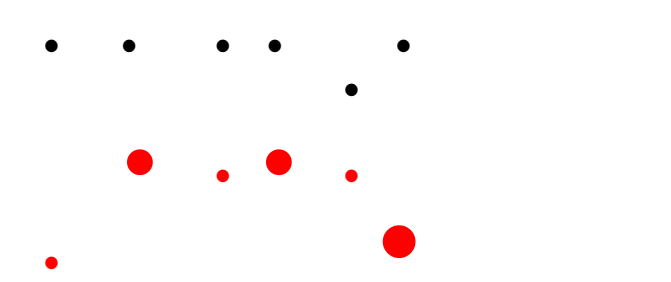

It may be hard to see, but Subject C's pitch starts somewhere in the middle of the vertical range, and keeps the height, until it falls down on "to" and rises up on the final "who". The key part of the prosody here is the final rising for a yes-no question. The rise is superimposed on the final monosyllabic "who" alone in the native target, while the subject realizes the rise with the low "to" plus the high "who". It is interesting that the subject cannot superimpose the rise on "who" but makes a compromise somehow to express the intended intonation for a question. The next example is a short sentence composed of five syllables. It shows that while the target presents a gradual rise from the first to the last syllables, the subject starts from the high position moving down to the bottom and finally up to the same high position. In (9) we see another same type of intonation pattern.

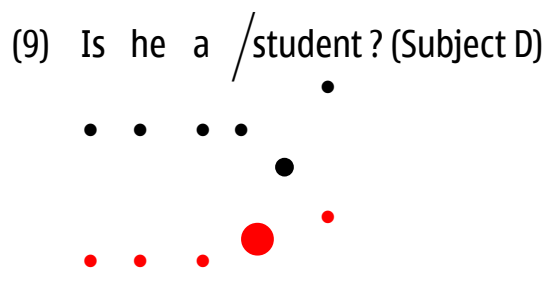

In this case, the subject inserts a weak vowel between [s] and [t] in "student", producing it as a three-syllable word. Here again, the intonation contour starts in the middle and falls down on "stu-", then goes up on the final "-dent". As the third example, we take a look at a very short sentence.

(10) All of / Us? (Subject E) 
In this case, the contour moves between high and middle. It starts from high ("All") and falls down to the middle ("of"), and rises again in the end on "us". Note that before the rise there is a fall in all the three examples.

We have observed six examples, three with falling intonation and three with rising intonation. What we have noticed from the examples is that when the contour falls, there is a rise before it, while when the contour rises, there is a fall before it. These fall and rise are those taking place in the key part of the contour which plays a crucial role for the intonation. Then, why are the contours the way they are? It is worth drawing our attention to Obligatory Contour Principle (OCP), first proposed by Goldsmith (1979). "OCP effect" prevents two syllables with the same tone from being adjacent to each other, ending up with a tone contour. The status of OCP in phonological theory is rather complicated, but here it is assumed to be a kind of phonological constraint. It is formalized in prose as follows:

\section{(11) Obligatory Contour Principle}

(At the key movement of an intonation contour, the prior syllable should bear a different tone.)

The constraint (11) is purely phonological and it is, so to speak, an approach run for a jump (or a dive). It should also be pointed out that though the syllable length and the stress on each syllable are equal, the pitch moves up and down across all the subjects, who manage to realize sentential meaning expressed in intonation patterns, even though the tonal pattern (and tonicity) is wrong. In sum, we have noticed in the first stage of intonation acquisition the following two points. First, a fall in the crucial part of contour needs a prior rise and a rise needs a prior fall. Second, the learners manage to handle pitch, though insufficiently, but can hardly modulate intensity and duration.

\section{DISCUSSION}

We have seen the learner's prosodic system in the initial stage of acquisition. First and foremost, we discussed the asymmetrical functioning between pitch, intensity and duration. It is widely recognized that English accent is a combination of these three parameters. As Wells (2006) puts it, stress is realized by a combination of loudness, duration and pitch. Stressed syllables are louder in voice, longer in duration and higher in pitch than unstressed syllables. The three parameters for prosody act in cooperation in English. Now, as a working hypothesis, Let us assume that these three parameters are acquired individually by Japanese learners of English in the course of learning. There are reasonable grounds for assuming this, which I discuss below.

Recent studies by Kawahara and his colleagues (Erickson and Kawahara 2015, Kawahara, Erickson and Shimizu 2015) have revealed some interesting facts related to these parameters. Consider the case of two [a], which are different from each other only in intensity; one is produced with more intensity and the other with less intensity. In the case of native speakers of English, as the vowel is more intensified, the jaw opens 
more widely and the opening duration is longer. This fact is supported by articulatory evidence. For any vowel, the jaw is opened exactly with same speed, with equal length of time. Native speakers open their jaw constantly with same speed for any vowel. Thus, because of this constant speed, the wider the jaw opens, the more time it takes for the jaw opening. Therefore, intensity is physiologically related to duration. On the contrary, native speakers of Japanese, when they produce the more intensified [a], jaw opening speed itself is higher than when they produce the less intensified [a]. This means that regardless of the degree of intensity, articulatory speed is more or less fixed and they control the articulation so that the speed is high when the jaw opens wide while it is slow when the jaw opens narrowly. The result of these studies attests to mora-timing in Japanese from a pure physiological perspective.

A series of researches by Sugahara (Sugahara 2011, 2016 inter alia) suggest that native speakers of Japanese heavily rely on pitch information. The native speaker subjects who participated in her experiment cannot identify the locus of stress when the pitch information is not available. It follows from the result that to Japanese native speakers the other parameters than pitch should be more difficult to acquire. Based on these and other findings, it is not unreasonable to claim that the three parameters determining stress are acquired individually in the learner's phonological system, and that it is pitch that the learner can access the first and the most easily. The special role of pitch among the parameters is due to the phonological system of Japanese where only (downward) pitch movement plays a part in lexical accentuation. Thus, the learner transfers this lexical accentuation to his/her interlanguage system in which the pitch movement is utilized to represent intonation. In the elementary stage when the other two parameters, namely intensity and duration, have not been acquired yet, pitch is the only way to manipulate prosody. Based on the constraint in (11), we can predict that only $\mathrm{H}(\mathrm{LH})$ and $\mathrm{L}(\mathrm{HL})$ patterns are permitted, wherein the parenthesized parts are key movement to denote intonation. To advance from this elementary stage, the learner has to overcome, eliminate this constraint to produce the prohibited patterns like $\mathrm{L}(\mathrm{LH})$ or $\mathrm{H}(\mathrm{HL})$. Thus, the first problem for the elementary learners is purely phonological.

Then, what about the problem of tonicity which advanced learners are suffering? Let us take a look at two examples.

(12) I think it was ridiculous. (Subject B)

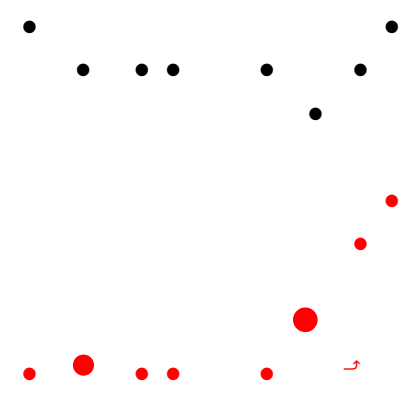


(13) What did you say her name was? (Subject D)

$\bullet$

In (12) and (13), a pronoun and an interrogative are produced with high pitch respectively, resulting in additional and misleading prominence on the lexical items. Thus, the problem with tonicity is already observed at this stage. It is further suggested that even though the learner overcomes the phonological OCP constraint and proceeds to a more advanced level, the interface constraint between phonology and syntax still remains in the phonological system of the learner and is a barrier to further advancement.

We have examined the process of the acquisition of English intonation by Japanese learners. We have discussed that they first overcome a type of OCP constraint which is phonological, but that in the next stage they still have to control another type of phonology-syntax interface constraint. This process is schematized below in (14)

(14) Process of intonation acquisition

Elementary Stage

$\downarrow$ Phonological OCP constraint to be controlled

Advanced Stage

$\downarrow$ Phonology-syntax interface constraint to be controlled

Semi-native-like Stage

To really reach the native-like stage, the learner has to overcome some pragmaticsrelated constraints. However, this is not in the scope of the present study and it shall be discussed elsewhere in the future. 


\section{REFERENCES}

Cinque, G. 1993. A null theory of phrase and compound stress. Linguistic Inquiry, 24, 239-297.

Erickson, D. and S. Kawahara. 2015. A Practical Guide to Calculating Syllable Prominence, Timing and Boundaries in the C/D Model. Onsei Kenkyu (Journal of the Phonetic Society of Japan) 19-2, 16-21.

Goldsmith, J. 1979. Autosegmental Phonology. New York: Garland Press.

Kamiyama, T. 2008. Datsu Nihongo Namari. Osaka University Press.

Kawahara, S., D. Erickson and A. Shimizu. 2015. Edge Prominence and Declination in Japanese Jaw Displacement Patterns: A View from the C/D Model. Onsei Kenkyu (Journal of the Phonetic Society of Japan) 33-43.

Saito, H. 2006. Nuclear-stress placement by Japanese learners of English: Transfer from Japanese. In Prosody and Syntax edited by Y. Kawaguchi, I. Fonagy and T. Moriguchi, 125-139. Amsterdam: John Benjamins.

Saito, H. and I. Ueda. 2007. Does accentuation of L1 transfer to L2 prosody? A preliminary study on Osaka and Tokyo dialect speakers' pronunciation of English. In Proceedings of 2nd Phonetics Teaching and Learning Conference, 1-4. University College London. Shimizu, K. 1995. Eigo Onseigaku: Rironnto Gakushu. Keiso Shobo.

Sugahara, M.2011. Identification of English primary stress and bias toward strong wordinitial syllables: native vs. Japanese listeners. Proceedings of ICPhS XVII. Hong Kong.

Sugahara, M. 2016. Is Japanese listeners' perception of English stress influenced by the antepenultimate accent in Japanese? Comparison with English and Korean listeners. Doshisha Studies in English 96, 61-111.

Sugimoto, J. 2003. Eigorashisaha rizumukara. In Otonano Eigohatsuonkoza. edited by Eigo Onseigaku Kenkyukai. 63-88. Nihon Hoso Kyokai Shuppan.

Sugito, M. 1996. Nihonniinnno Eigo. Izumi Shoten.

Sugito, M. 2012. Nihonngono Akusennto, Eigono Akusennto. Hituzi Shobo.

Ueda, I. and H. Saito. 2010. The interface between phonology, pragmatics and syntax in nuclear misplacement. Proceedings of the 2009 Mind/Context Divide Workshop pp. 116-22. Cascadella Press.

Ueda, I. and H.Saito (2012) Tonic misplacement by Japanese learners of English. Exploring English Phonetics. Cubrović, B. and Paunović, T. (eds.) pp. 73-83. Newcastle-uponTyne: Cambridge Scholars Publishing.

Takebayashi, S. and H. Saito (2008) Eigo Onseigaku Nyumon. Tiashukan.

Takebayashi, S. A. Shimizu and H. Saito (2013) Shokyu Eigo Onseigaku. Taishukan.

Wells, J. 2006. English Intonation. Cambridge: CUP. 


\section{SUMMARY}

\section{THE ACQUISITION OF ENGLISH INTONATION BY JAPANESE ELEMENTARY LEARNERS: EFFECTS OF A PHONOLOGICAL CONSTRAINT}

Although the first stage of the acquisition of English intonation by Japanese learners has been anecdotally described in literature, detailed data from case studies have not been presented. In this study, some characteristics of the interlanguage phonological system are described based on the result of a preliminary experiment on elementarylevel subjects. It is argued that there is a phonological constraint, which hinders the learner from proceeding further. It is also claimed that the three parameters composing English stress, namely intensity, pitch and duration, are acquired individually, and that elementary learners rely on pitch alone. Finally, it is suggested that the acquisition of intonation is a process wherein the learner overcomes and attains a command of different types of constraints.

KEYWORDS: English intonation, acquisition, second language phonology, foreign accent, constraints on development.

(Original scientific paper received: 15.05.2016; revised 28.05.2016; accepted 11.07.2016) 